\title{
ANALISIS REGANGAN BAJA TULANGAN PADA STRUKTUR PILE CAP EMPAT TIANG METODE STRUT AND TIE MODEL
}

\author{
Sukarman', Djoko Sulistyo', Inggar Septhia Irawati ${ }^{1}$ \\ ${ }^{1}$ Departemen Teknik Sipil dan Lingkungan, Fakultas Teknik, Universitas Gadjah Mada, Yogyakarta \\ Email: sukarman@mail.ugm.ac.id
}

\begin{abstract}
Pile cap is one of the many types of structures that are entirely Disturbed-region. The structure undergoes a nonlinear strain because it was meeting point of the pile and column with centralized forces. In addition, geometry changes occur at the meeting between the column, pile cap, and pile, so the Bernoulli concept is no longer suitable for this condition. Pile cap testing consists of two groups of specimens and each group consists of three specimens. The first group was designed using the STM method (SNI 2847: 2013 Appendix A) and the second group was designed using conventional methods (SNI 2847: 2013 Article 15). Loading is the application of a centralized static load that is channeled through a centric column until the pile cap structure has collapsed. The results show that: (1) The flexural reinforcement which experiences the first yield condition both on the pile cap testing of the STM method and in the conventional method was the $X$ direction flexural reinforcement (outsidest flexural reinforcement). (2) The average strain of the yield conditions and load on the pile cap STM method were $2242 \mu \varepsilon$ and $528.97 \mathrm{kN}$, whereas the conventional method were $2436 \mu \varepsilon$ and $437.03 \mathrm{kN}$. (3) Increasing the load capacity of the yield conditions $\left(P_{y}\right)$ of the pile cap STM method and conventional method on the plan load $\left(P_{n}\right)$ were $32.2 \%$ and $9.3 \%$.
\end{abstract}

Keywords: pile cap, four piles, Strut and Tie Model (STM)

\begin{abstract}
ABSTRAK
Pile cap merupakan salah satu dari jenis struktur yang sepenuhnya merupakan daerah terganggu (Disturbedregion). Struktur tersebut mengalami regangan non-linear karena merupakan titik pertemuan pile dan kolom dengan gaya-gaya terpusat. Selain itu, terjadi perubahan geometri pada pertemuan antara kolom, pile cap, dan pile, sehingga konsep Bernoulli tidak cocok lagi pada kondisi tersebut. Pengujian pile cap terdiri dari dua kelompok benda uji dan masing-masing kelompok terdiri dari tiga buah benda uji. Kelompok pertama dirancang menggunakan metode STM (SNI 2847:2013 Lampiran A) dan kelompok kedua dirancang menggunakan metode konvensional (SNI 2847:2013 Pasal 15). Pembebanan berupa penerapan beban statik terpusat yang disalurkan melalui kolom sentris sampai struktur pile cap mengalami keruntuhan. Hasil menunjukkan bahwa: (1) Tulangan lentur yang mengalami kondisi leleh terlebih dahulu baik pada pengujian benda uji pile cap metode STM maupun pada metode konvensional adalah tulangan lentur arah X (tulangan lentur terluar). (2) Rata-rata regangan kondisi leleh dan beban pada benda uji pile cap metode STM adalah $2242 \mu \varepsilon$ dan $528,97 \mathrm{kN}$, sedangkan pada metode konvensional adalah $2436 \mu \varepsilon$ dan 437,03 kN . (3) Peningkatan kapasitas beban kondisi leleh $\left(P_{y}\right)$ pada benda uji pile cap metode STM dan metode konvensional terhadap beban rencana $\left(P_{n}\right)$ adalah $32,2 \%$ dan $9,3 \%$.
\end{abstract}

Kata kunci: pile cap, empat tiang, Strut-and-Tie Model (STM) 


\section{PENDAHULUAN}

Pile cap merupakan salah satu elemen yang sangat penting dari suatu struktur. Hal tersebut dikarenakan pile cap memiliki peranan besar dalam pendistribusian atau penyaluran beban struktur dari kolom ke tiang pancang untuk selanjutnya diteruskan menuju tanah. Sehingga dalam perencanaan, diperlukan suatu kepastian tentang keamanan struktur terhadap kemungkinan kegagalan pada struktur tersebut.

Selama ini, perancangan struktur beton telah banyak diselidiki berdasarkan analisis batas (limit analysis). Metode tersebut belum meluas karena muncul berbagai pertimbangan terkait perilaku struktur beton yang sangat beragam. Pendekatan melalui limit analysis menurut Hardjasaputra (2002) dapat dinyatakan dalam dua kategori, pertama berdasarkan "lower-bound" (statik) dan kedua berdasarkan "upper-bound" (kinematik). Pendekatan metode statik dapat langsung diterapkan dalam perencangan dan detailing karena kekuatan beton dan baja tulangan yang dibutuhkan dapat diperoleh dari sistem keseimbangan gaya-gaya dalam dari struktur yang dibebani sampai beban batas (ultimate load). Sedangkan pendekatan metode kinematik umumnya digunakan pada rancangan yang sudah ada (existing design) karena keseimbangan dari model yang dipakai hanya berlaku sesuai dengan keadaan tertentu. Sampai saat ini model yang dianggap konsisten dan rasional dalam perencanaan struktur beton adalah pendekatan melalui "strut and tie model" (STM). STM merupakan suatu metode perancangan yang mendasarkan pada asumsi bahwa aliran gaya-gaya dalam struktur beton dan terutama pada daerah yang mengalami distorsi dapat didekati sebagai suatu sistem rangka batang yang terdiri dari strut (batang tekan atau penunjang) dan tie (batang tarik atau pengikat). Sehingga strut and tie merupakan resultante dari medan tegangan (stress field). Pada strut yang bekerja adalah beton sedangkan pada tie yang bekerja adalah tulangan yang terpasang.

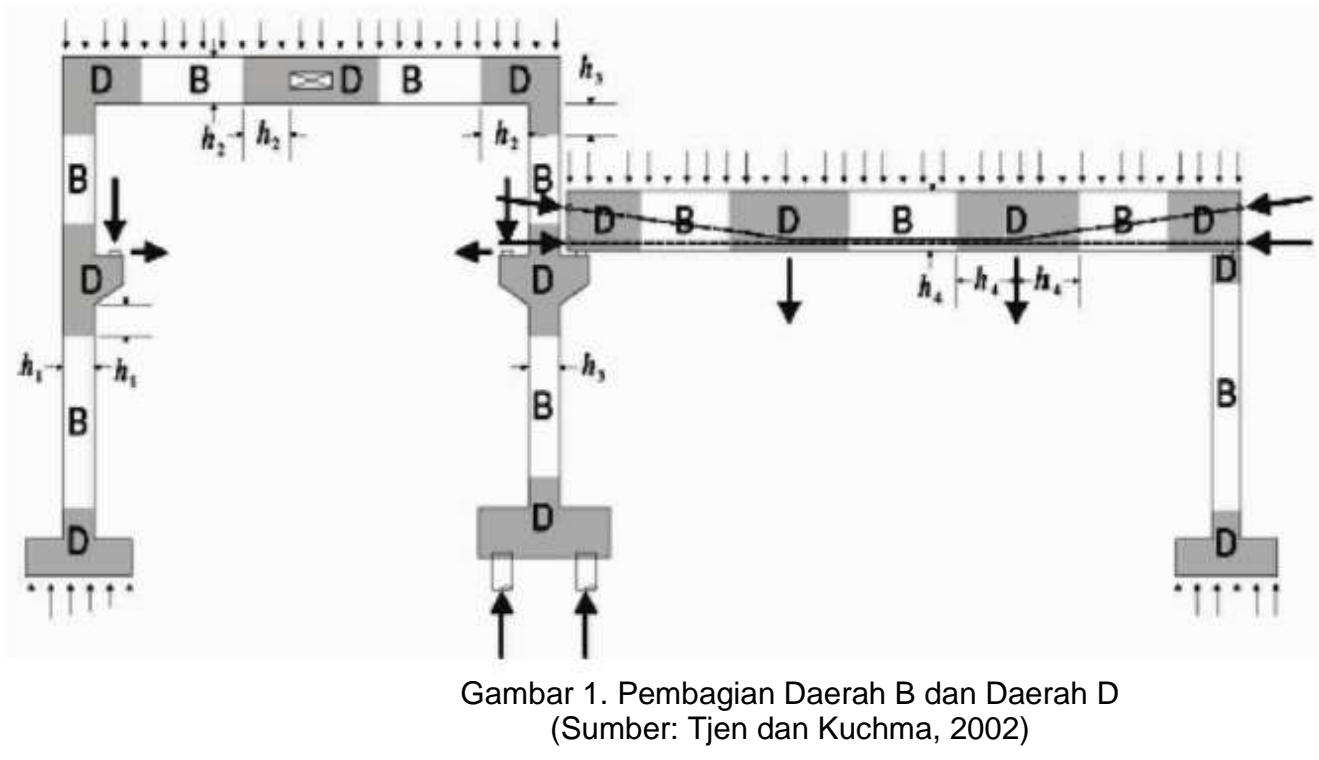

Hardjasaputra dan Tumilar (2002), STM berawal dari Truss analogy model yang sebenarnya pertama kali diperkenalkan oleh Ritter pada tahun 1899 dan Morsch pada tahun 1902. Dengan memperhatikan pola retak yang terjadi akibat suatu beban $(F)$, Morsch menggunakan model rangka batang (Truss) untuk menjelaskan aliran gaya (load path) untuk transfer beban (F) ke tumpuan 
yang terjadi pada struktur beton bertulang dalam keadaan retak.

Schlaich et al. (1982-1993) membagi suatu struktur pada strut and tie model menjadi dua daerah, yaitu daerah B (Bernoulli) yang pada umumnya didasarkan pada distribusi tegangan linear menurut hipotesa Bernoulli. Sedangkan daerah D (Discontinuity, Disturbance) merupakan daerah atau tempat terjadinya distribusi tegangan nonlinear yang diakibatkan oleh diskontinuitas geometri, statika, dan atau kombinasi dari keduanya.

Martin dan Sanders (2007) menyebutkan bahwa STM adalah suatu pendekatan yang digunakan untuk merancang daerah diskontinuitas (D-region) pada struktur beton bertulang dan prategang. STM menyederhanakan tegangan yang kompleks pada suatu D-region ke dalam konfigurasi truss sederhana sebagai jalur tegangan uniaksial. Setiap jalur tegangan uniaksial dianggap sebagai elemen STM.

Souza et al. (2009) mengajukan model pile cap yang didasarkan pendekatan strut and tie model. Model berupa pile cap yang dibebani 1 kolom yang ditopang 4 tiang, selanjutnya dikalibrasi dengan hasil pengujian dari 6 pengujian dengan total 129 objek, yaitu dari Blevot dan Fremy (1967), Clarke (1973), Suzuki et al. (1988), Suzuki et al. (1999), Suzuki et al. (2000), dan Suzuki et al. (2002). Model tersebut berhasil

\section{METODE}

Metode yang digunakan dalam penelitian ini merupakan metode eksperimen. Penelitian ini dilakukan di Laboratorium Teknik Struktur, Departemen Teknik Sipil dan Lingkungan, Fakultas Teknik, Universitas Gadjah Mada. Benda uji pile cap dalam penelitian ini terdiri dari 6 buah yaitu 3 buah sebagai pile cap metode STM (terdiri dari PC-SS-4P-1, PC-SS-4P-2, dan PC-SS-4P2) dan 3 buah sebagai pile cap metode konvensional (terdiri dari PC-KS-4P-1, PCKS-4P-2, dan PC-KS-4P-3). Ukuran prototipe pile cap metode konvensional dan memperkirakan $87 \%$ tipe kegagalan (geser atau lentur) dari 129 pile cap dengan tepat.

Shah et al., 2011 melakukan penelitian dengan merancang beberapa struktur meliputi: 4 pile cap, 6 korbel, 3 balok tinggi, serta dapped beam menggunakan STM yang kemudian diuji di laboratorium menggunakan beban monotonik. Kapasitas beban hasil pengujian dibandingkan dengan beban rencana. Hasil pengujian menunjukkan bahwa kapasitas geser hasil eksperimen sedikit lebih besar jika dibandingkan dengan prediksi menggunakan STM dengan nilai rerata 1,17 , yang berarti bahwa kapasitas geser eksperimen $17 \%$ lebih besar bila dibandingkan dengan kapasitas geser teoritis yang dirancang menggunakan STM. Pile cap merupakan struktur yang mengalami regangan non-linear karena pada titik pertemuan dengan pile dan kolom terdapat gaya-gaya terpusat. Selaian itu, terjadi perubahan geometri pada pertemuan antara kolom, pile cap, dan pile, sehingga konsep Bernoulli tidak cocok lagi pada kondisi tersebut. Oleh karena itu pada penelitian ini, metode STM akan diaplikasikan dalam proses perancangan pile cap. Selain itu metode konvensional juga akan digunakan sebagai pembanding. Kedua metode tersebut akan menghasilkan luas tulangan dan susunan tulangan yang berbeda yang kemudian akan dibandingkan perilakunya melalui pengujian eksperimental di laboratorium.

metode STM adalah $1550 \mathrm{~mm}$ x $1550 \mathrm{~mm} \times$ $450 \mathrm{~mm}$. Pile cap tersebut dirancang dengan beban rencana sebesar $2500 \mathrm{kN}$, selanjutnya dimensi tersebut diskala model 1:2,5 menggunakan Teori Buckingham (Suhendro, 2000). Untuk lebih jelasnya dapat dilihat pada Tabel 1. Untuk detail benda uji tersebut dapat dilihat pada Gambar 1 s.d 8, sementara untuk flowchart dalam perancangan benda uji pile cap metode STM dan konvensional dapat dilihat pada Gambar 1 dan 2. 
Tabel 1. Spesifikasi Benda Uji Pile Cap

\begin{tabular}{|c|c|c|c|}
\hline \multicolumn{2}{|c|}{ Benda Uji } & \multirow{2}{*}{$\begin{array}{c}\text { PC-KS } \\
620 \times 620 \times 180\end{array}$} & \multirow{2}{*}{$\begin{array}{c}\text { PC-SS } \\
620 \times 620 \times 180\end{array}$} \\
\hline Dimensi $(\mathrm{I} \times \mathrm{b} \times \mathrm{h}) \mathrm{mm}$ & & & \\
\hline & Arah $\mathrm{x}$ & 4 D10-183 & 6 D10-70 \\
\hline Tulangan Lentur & Arah y & $4 \mathrm{D} 10-183$ & $6 \mathrm{D} 10-70$ \\
\hline & Arah $x$ & $4 \mathrm{P} 8-185$ & 4 P8-185 \\
\hline Tulangan Susut & Arah y & $4 \mathrm{P} 8-185$ & $4 P 8-185$ \\
\hline Jumlah sampel & & 3 & 3 \\
\hline $\begin{array}{l}\text { Keterangan: } \\
\text { PC: pile cap; }\end{array}$ & & & \\
\hline
\end{tabular}

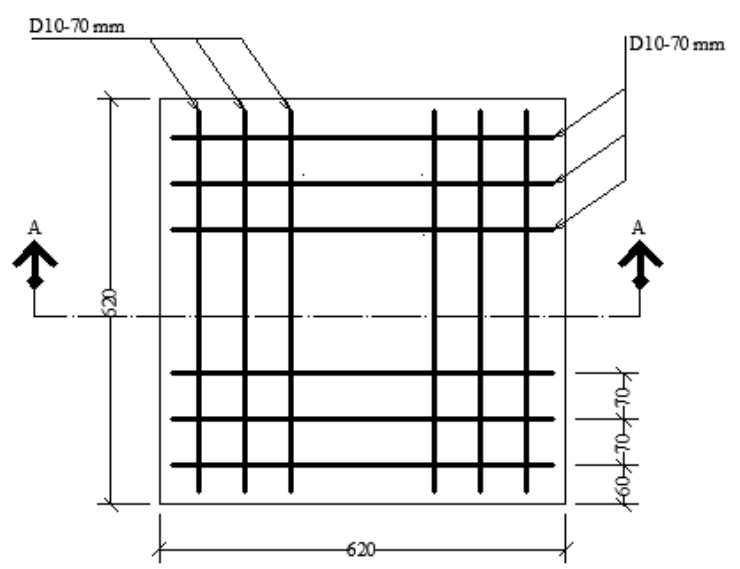

Gambar 2. Tulangan Lentur Pile Cap Metode STM

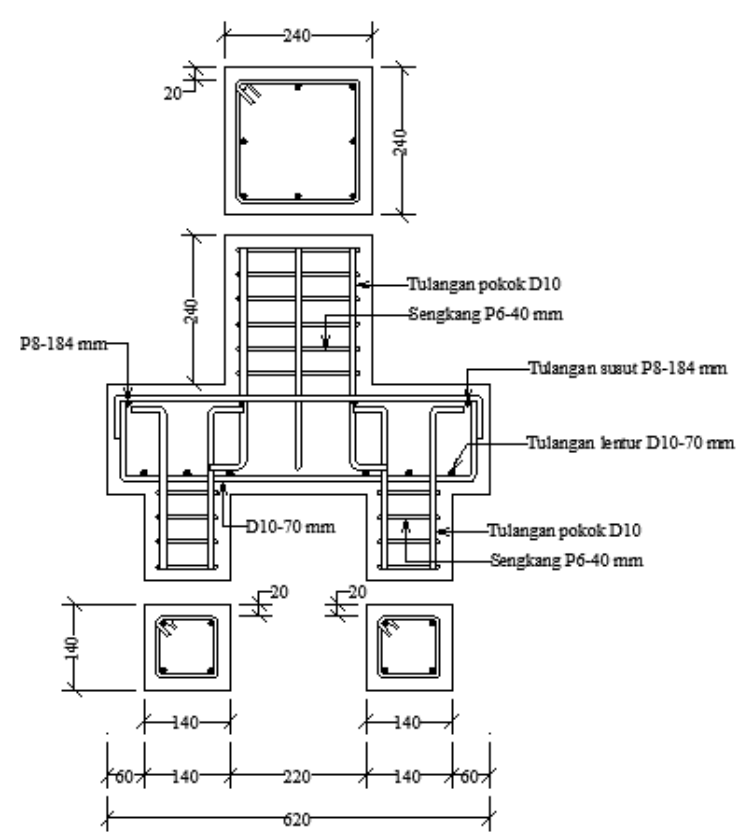

Gambar 4. Potongan Pile Cap Metode STM

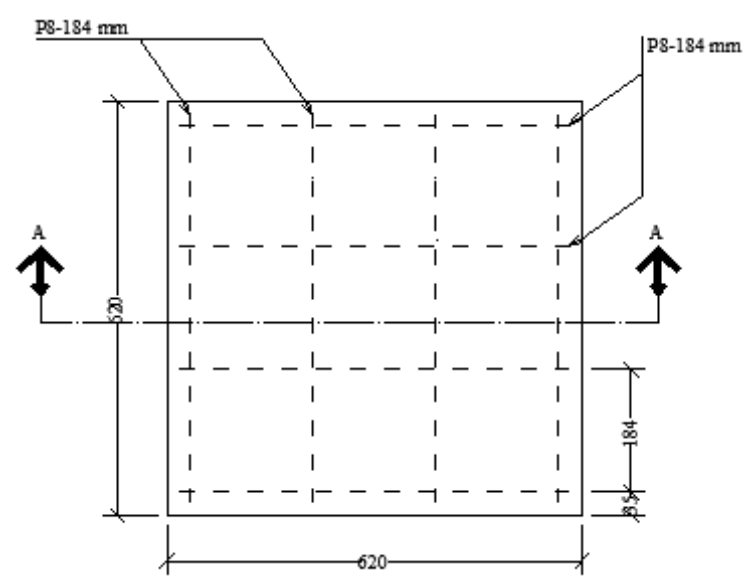

Gambar 3. Tulangan Susut Pile Cap Metode STM

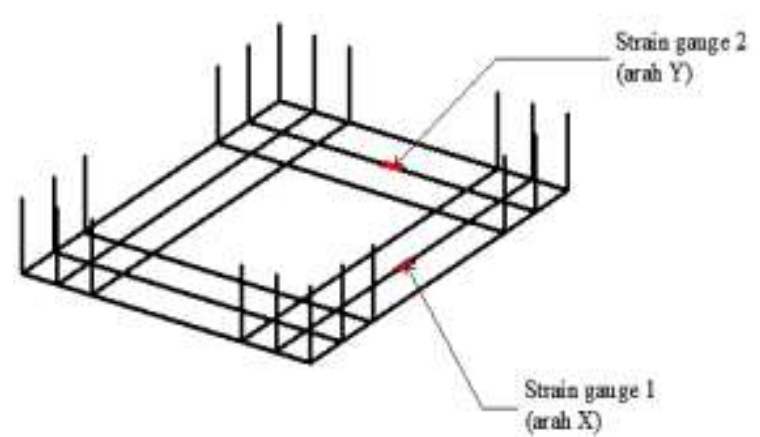

Gambar 5. Potongan Strain Gauge Baja Pada Pile Cap Metode STM 
Analisis Regangan ... (Sukarman/ hal 60-71)

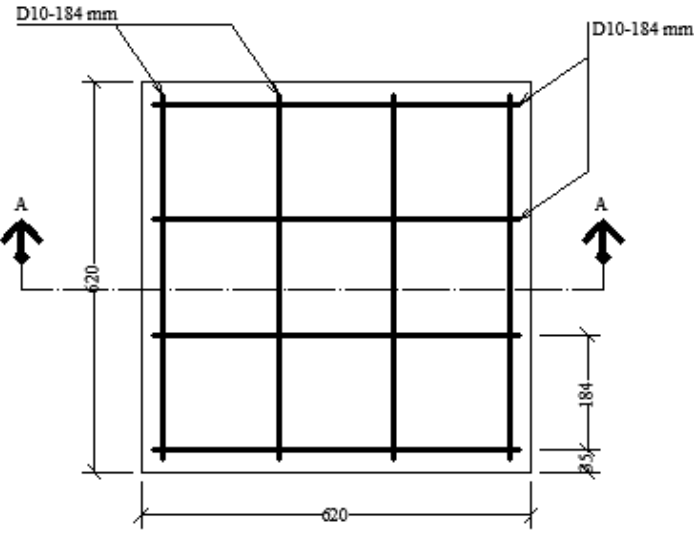

Gambar 6. Tulangan Lentur Pile Cap Metode Konvensional

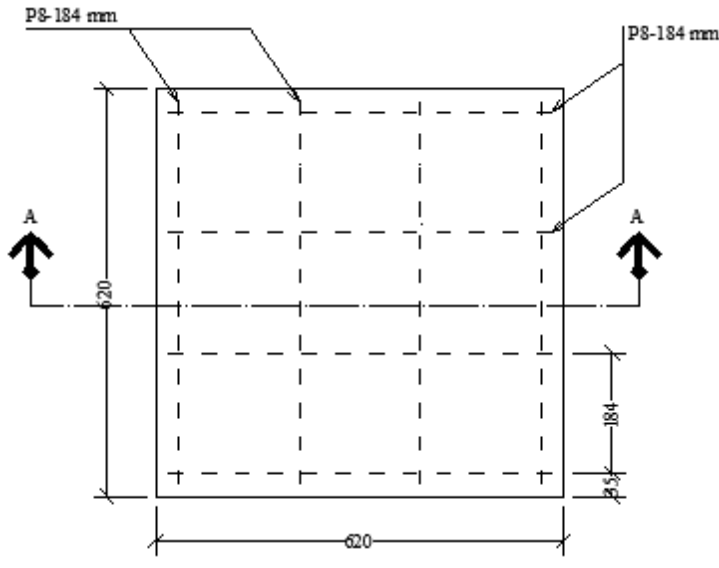

Gambar 7. Tulangan Susut Pile Cap Metode Konvensional

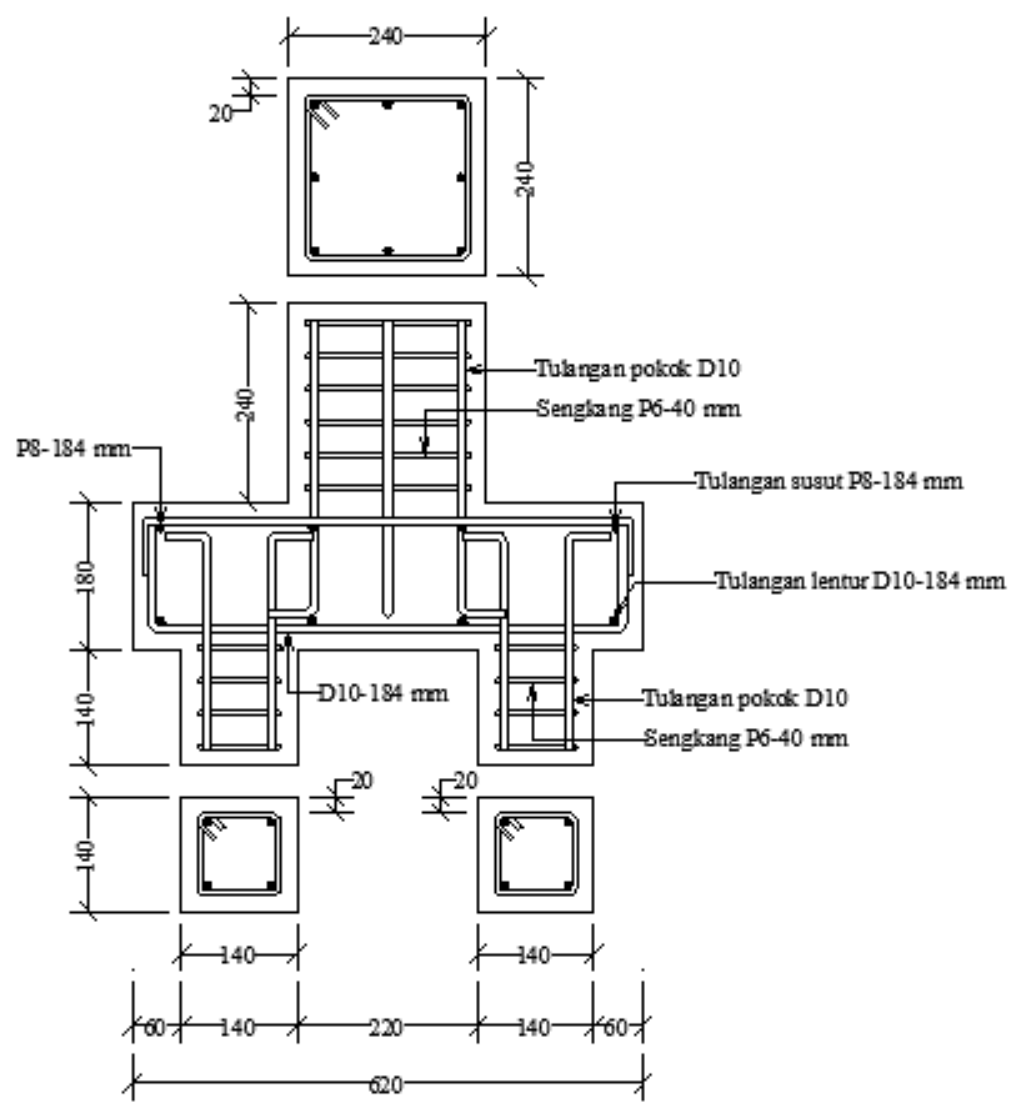

Gambar 8. Potongan Pile Cap Metode Konvensional

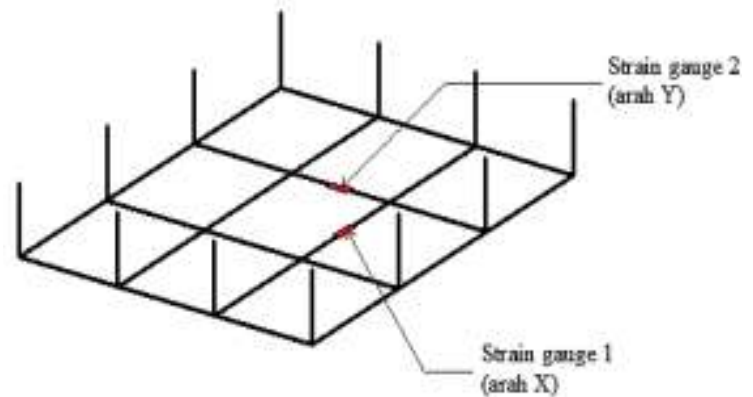

Gambar 9. Potongan Strain Gauge Baja Pada Pile Cap Metode Konvensional 


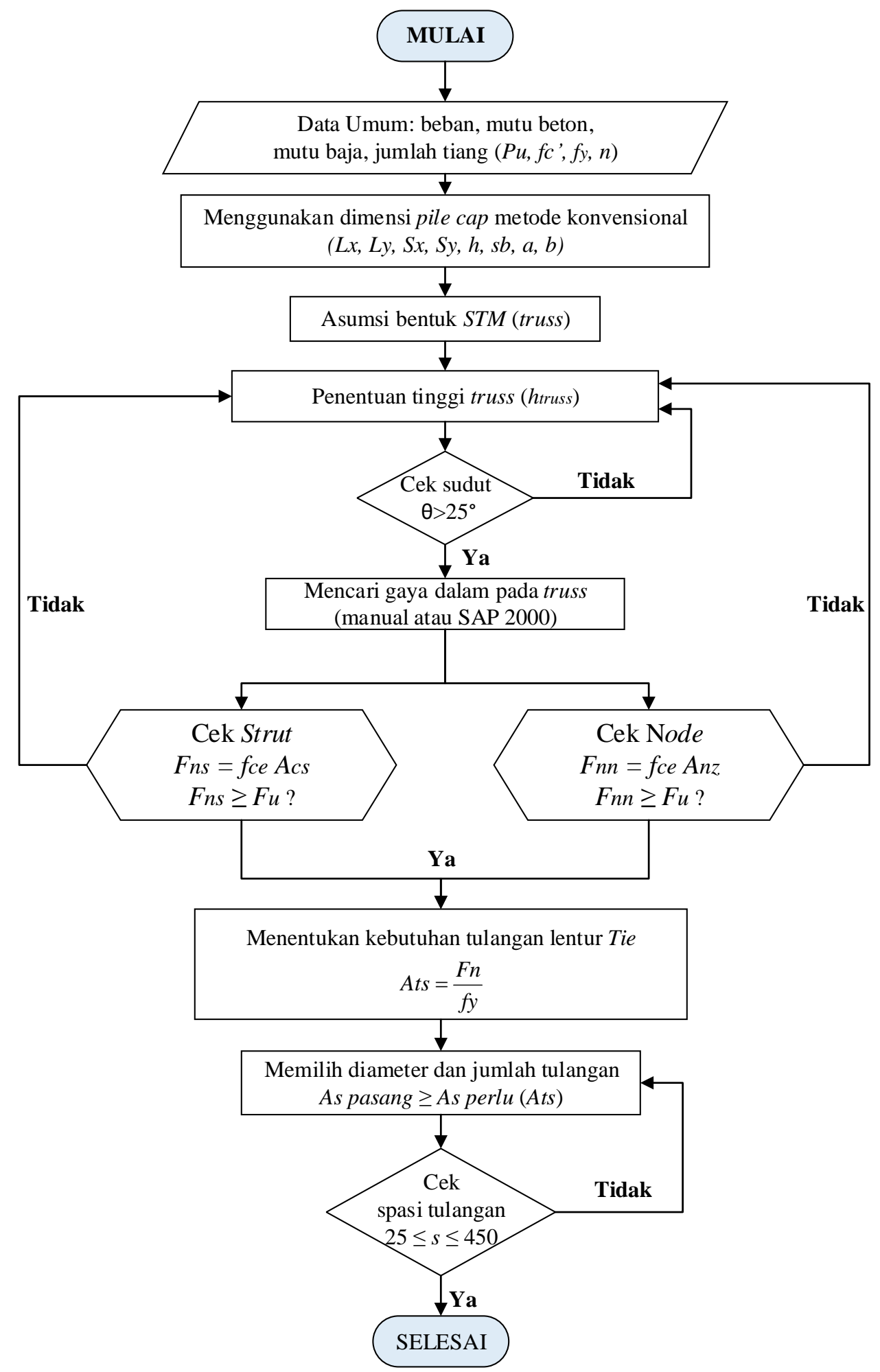

Gambar 10. Flowchart Perancangan Pile Cap Metode STM 


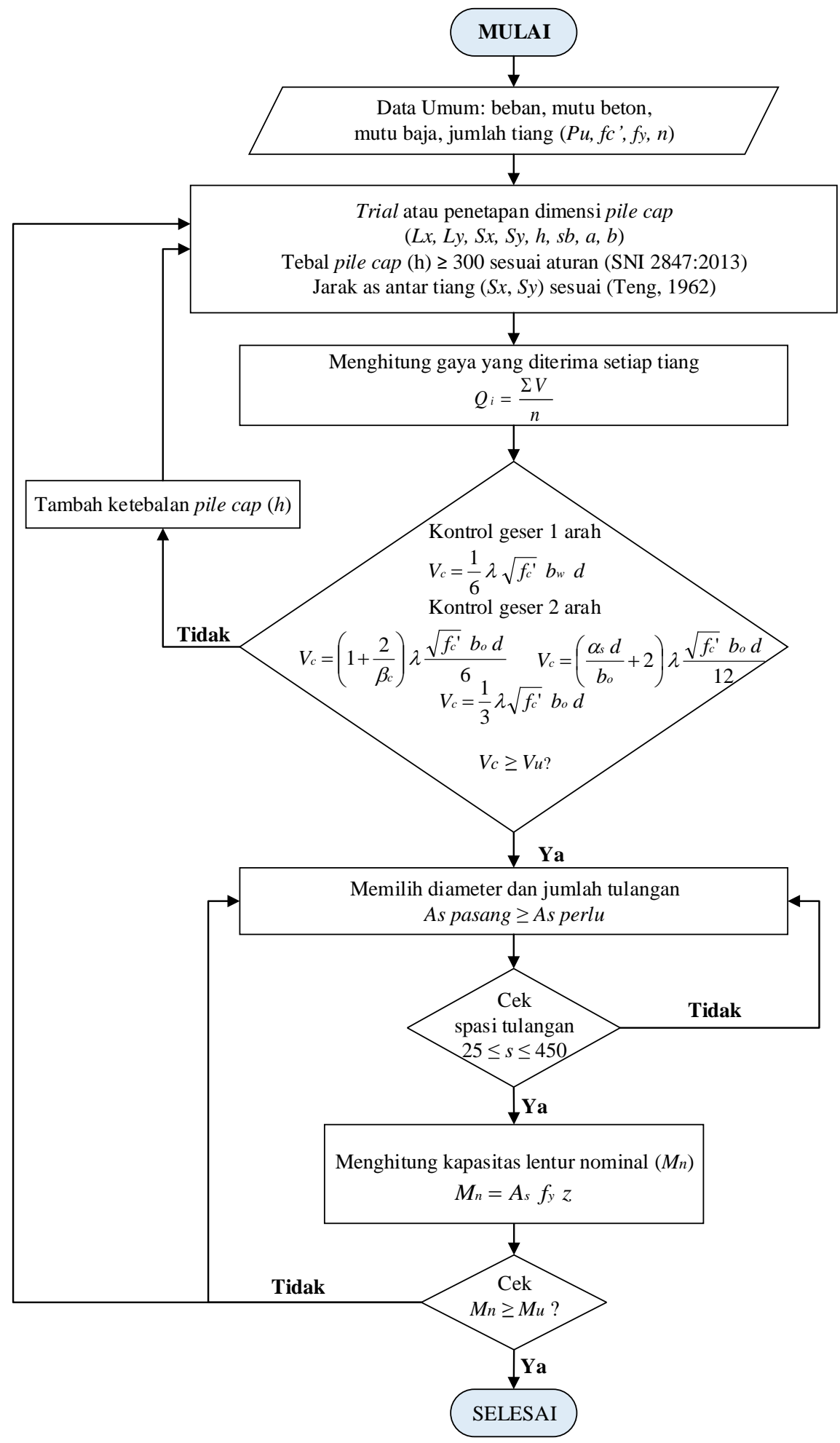

Gambar 11. Flowchart Perancangan Pile Cap Metode Konvensional

Beberapa tahapan penelitian ini antara lain meliputi: (1) pengujian mutu material, (2) pembuatan benda uji, (3) perawatan beton, (4) pengujian struktur pile cap. Pengujian mutu material atau pengujian pendahuluan meliputi uji kuat tarik baja tulangan dan uji silinder beton (kuat tekan beton). Mutu beton yang dipakai dalam penelitian ini adalah K325 atau 27,5 MPa dengan nilai slump $100 \pm 20 \mathrm{~mm}$ serta ukuran agregat kasar terbesar $20 \mathrm{~mm}$ yang langsung dipesan dari Batching Plant. Pembuatan benda uji meliputi pembuatan bekisting, perakitan tulangan, pemasangan strain 
gauge, serta pengecoran benda uji. Perawatan beton (curing) dilakukan agar benda uji terjamin kelembapanya. Selanjutnya pengujian struktur pile cap dilakukan dengan menerapkan beban statik terpusat yang disalurkan melalui kolom sentris sampai struktur pile cap mengalami keruntuhan. Untuk detail benda uji pile cap yang sudah siap untuk diuji dapat dilihat pada Gambar 12.

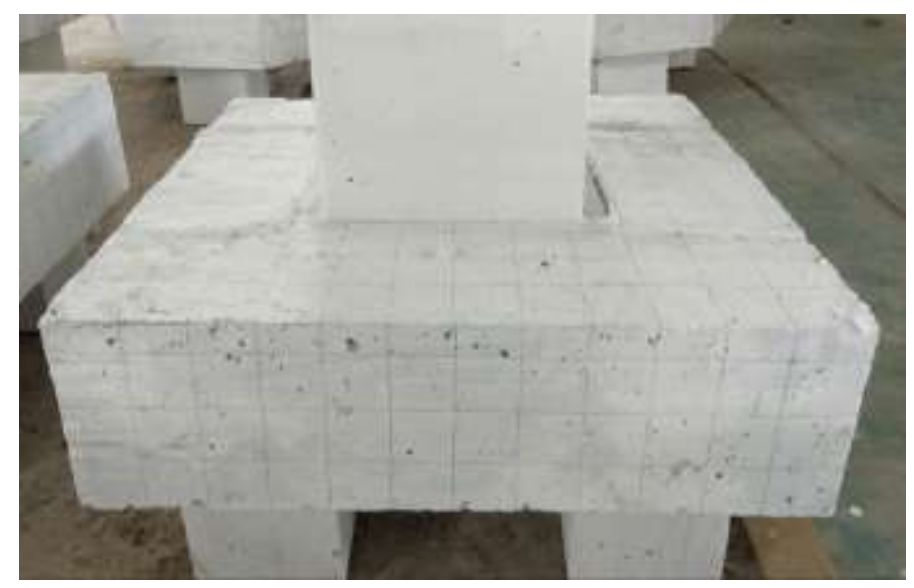

Gambar 12. Hasil Pembuatan Benda Uji Pile Cap

Tahapan pengujian pile cap dilakukan setelah berumur 28 hari. Sebelum dilakukan pengujian, pengecekan strain gauge harus dilakukan agar saat pengujian data regangan baja yang ditinjau dapat terbaca. Selanjutnya dilakukan seting up benda uji dimana semua peralatan untuk pengujian dipasang seperti bearing plat, tumpuan (sendi), hydraulic jack, load cell, serta data logger. Setting up pengujian tersebut dapat dilihat seperti pada Gambar 13.

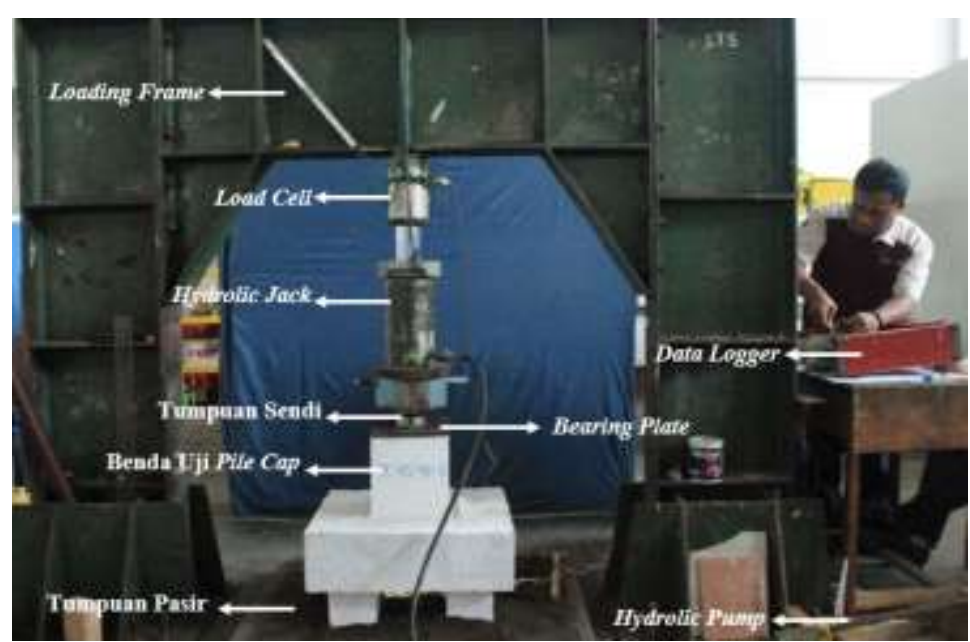

Gambar 13. Setting-up Pengujian

\section{HASIL DAN PEMBAHASAN}

Pengujian pendahuluan untuk kuat tarik baja tulangan dilakukan di Laboratorium Bahan Teknik, Departemen Teknik Mesin dan Industri, Fakultas Teknik, Universitas Gadjah Mada. Pengujian dilakukan untuk mengetahui karakteristik dari baja tulangan yaitu tegangan leleh, tegangan ultimit, serta regangan yang terjadi. Baja tulangan yang digunakan pada benda uji pile cap adalah D10 (BJTD) yang berfungsi sebagai 
tulangan lentur. Pengujian kuat tarik baja tulangan dilakukan untuk mengetahui kualitas baja tulangan dengan cara meninjau nilai tegangan dan regangan baja saat mencapai kodisi leleh dan ultimit. Hasil pengujian kuat tarik baja tulangan dapat dilihat pada Tabel 2.

Tabel 2. Hasil pengujian kuat tarik baja tulangan D10 mm

\begin{tabular}{cccc}
\hline Kode & $\begin{array}{c}\text { Tegangan } \\
\text { Leleh }\left(f_{y}\right) \\
(\mathbf{M P a})\end{array}$ & $\begin{array}{c}\text { Tegangan } \\
\text { Ultimit }\left(\boldsymbol{f}_{u}\right) \\
(\mathbf{M P a})\end{array}$ & $\begin{array}{c}\text { Regangan } \\
\text { Maksimal } \\
\left(\boldsymbol{\varepsilon}_{u}\right)\end{array}$ \\
\hline D10-1 & 388,26 & 573,19 & 0,334 \\
D10-2 & 461,91 & 632,43 & 0,278 \\
D10-3 & 430,69 & 644,44 & 0,248 \\
\hline
\end{tabular}

Berdasarkan Tabel 2 dapat disimpulkan bahwa tulangan D10 mm memiliki tegangan leleh rata-rata sebesar 426,96 MPa dengan regangan leleh sebesar $2135 \mu \varepsilon$, tegangan ultimit rata-rata sebesar 616,69 MPa, serta regangan maksimal rata-rata sebesar $287000 \mu \varepsilon$.

Pengujian kuat tekan silinder beton dilakukan di Laboratorium Struktur, Departemen Teknik Sipil dan Lingkungan, Fakultas Teknik, Universitas Gadjah Mada. Pengujian tersebut dilakukan untuk mengetahui nilai kuat tekan beton yang akan digunakan dalam pembuatan benda uji. Sebelum dilakukan pengujian, terlebih dahulu dilakukan perawatan benda uji dengan cara perendaman di dalam kolam air mulai dari benda uji berumur 2 hari dan dikeluarkan sehari sebelum dilakukan pengujian. Pengujian terhadap 4 buah silinder beton dilakukan setelah benda uji tersebut berumur 28 hari. Adapun hasil pengujian kuat tekan silinder beton dapat dilihat pada Tabel 3 .

Tabel 3. Hasil pengujian kuat tekan silinder beton

\begin{tabular}{ccc}
\hline Benda Uji & $\begin{array}{c}\text { Beban } \\
\text { (kN) }\end{array}$ & $\begin{array}{c}\text { Kuat Tekan } \\
\text { (MPa) }\end{array}$ \\
\hline 1 & 480 & 27,59 \\
2 & 525 & 29,88 \\
3 & 530 & 30,17 \\
4 & 460 & 25,97 \\
\hline
\end{tabular}

Berdasarkan hasil pengujian kuat tekan silinder beton pada umur 28 hari, nilai kuat tekan rata-rata hasil pengujian pada umur 28 hari yakni sebesar $28,40 \mathrm{MPa}$. Nilai kuat tekan tersebut 3,27\% lebih tinggi jika dibandingkan dengan yang direncanakan yakni sebesar $27,5 \mathrm{MPa}$.

Pada pengujian benda uji pile cap metode STM dan metode konvensional diperoleh hasil pembacaan regangan pada strain gauge 1 dan strain gauge 2. Strain gauge 1 digunakan untuk membaca hasil regangan baja tulangan lentur arah sumbu $X$. Selanjutnya strain gauge 2 digunakan untuk tulangan lentur arah sumbu Y (lihat Gambar 4 dan 8). Secara umum hasil pembacaan strain gauge pada baja tulangan menunjukkan bahwa semua tulangan lentur arah sumbu $X$ dan $Y$ baik pada pile cap metode STM dan metode konvensional sudah mengalami kondisi leleh. Untuk lebih jelasnya dapat dilihat pada Gambar 14. 


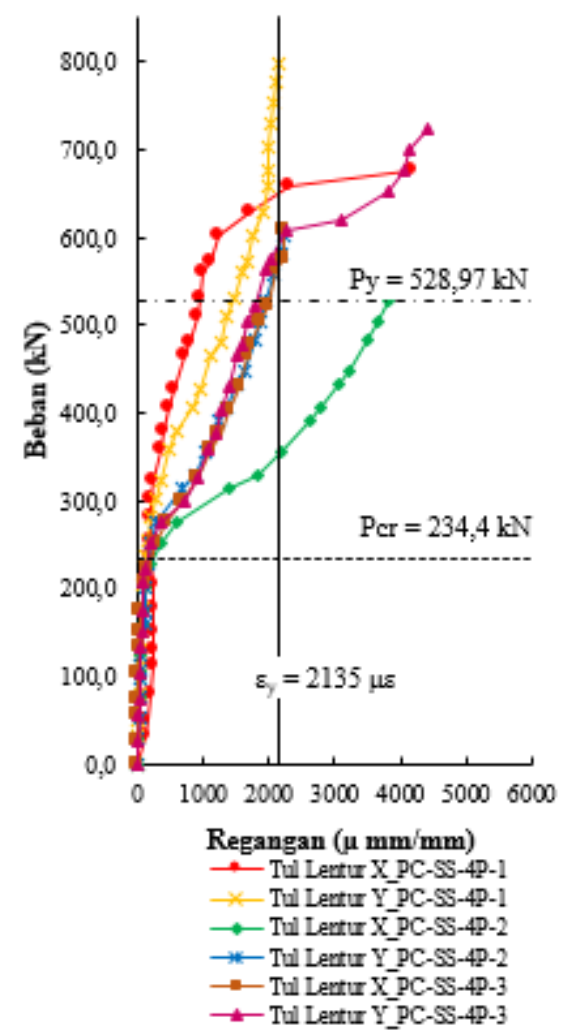

(a)

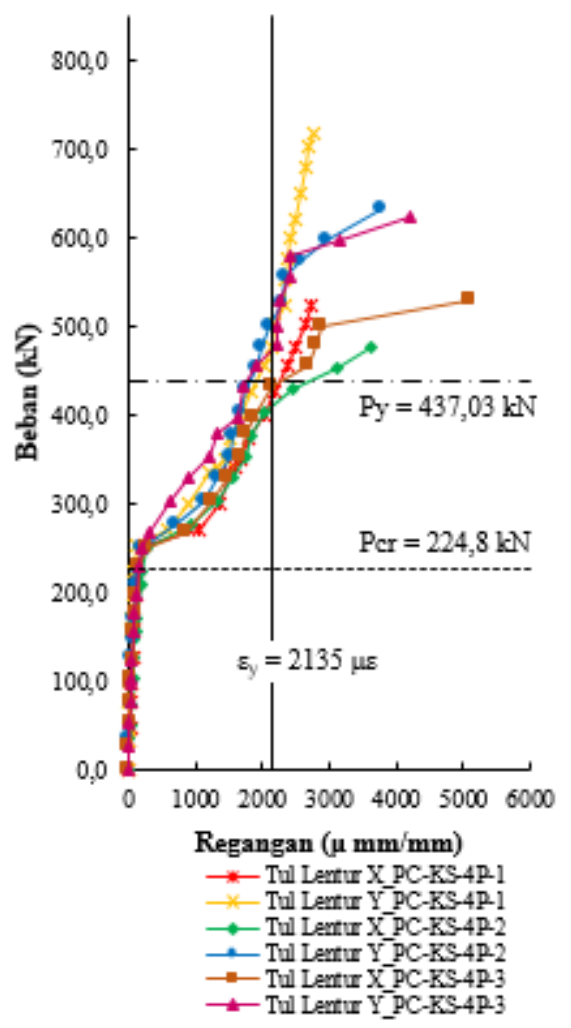

(b)

Gambar 14. Grafik Hubungan Regangan Tulangan Lentur Arah X dan Y Terhadap Beban Pada Benda Uji Pile Cap (a) Metode STM dan (b) Metode Konvensional

Pertambahan regangan pada tulangan lentur arah sumbu $\mathrm{X}$ untuk pile cap metode STM meningkat secara signifikan setelah mencapai rata-rata beban $249,9 \mathrm{kN}$, sedangkan pada pile cap metode konvensional regangan meningkat secara signifikan setelah mencapai rata-rata beban 224,8 kN. Sedangkan pertambahan regangan pada tulangan lentur arah sumbu Y untuk pile cap metode STM meningkat secara signifikan setelah mencapai ratarata beban $260,4 \mathrm{kN}$, sedangkan pada pile cap metode konvensional regangan meningkat secara signifikan setelah mencapai rata-rata beban $250,2 \mathrm{kN}$.

Secara umum penambahan regangan secara sigifikan terjadi pada saat retak awal (first crack). Hal tersebut terjadi dikarenakan saat beton mengalami retak maka distribusi tegangan sepenuhnya dilimpahkan pada baja tulangan. Sehingga regangan pada baja tulangan akan semakin meningkat seiring dengan meningkatnya tegangan yang diterima oleh baja tulangan tersebut.
Hasil pembacaan regangan tulangan lentur pada benda uji pile cap metode STM yang telah mencapai batas regangan leleh (2135 $\mu \varepsilon)$ untuk benda uji PC-SS-4P-1, PC-SS4P-2, dan PC-SS-4P-3 masing-masing sebesar $2299 \mu \varepsilon$, $2202 \mu \varepsilon$, dan $2225 \mu \varepsilon$ dengan beban masing-masing sebesar $656,8 \mathrm{kN}, 354,4 \mathrm{kN}$, dan 575,7 kN, sedangkan pada benda uji pile cap metode konvensional untuk benda uji PC-KS-4P-1, PC-KS-4P-2, dan PC-KS-4P-3 masingmasing sebesar $2178 \mu \varepsilon$, $2456 \mu \varepsilon$, dan 2676 $\mu \varepsilon$ dengan beban masing-masing sebesar $427,3 \mathrm{kN}, 428,4 \mathrm{kN}$, dan $455,4 \mathrm{kN}$.

Keseluruhan tulangan lentur arah sumbu $X$ baik pada benda uji pile cap metode STM maupun konvensional mengalami kondisi leleh lebih awal dibandingkan tulangan lentur arah sumbu $Y$. Hal tersebut dikarenakan tulangan lentur yang dipasang pada arah sumbu $X$ merupakan tulangan lentur terluar. Sehingga tegangan yang terjadi pada tulangan lentur arah sumbu $\mathrm{X}$ 
jauh lebih besar dari pada tulangan lentur arah sumbu Y.

Selanjutnya kapasitas beban kondisi leleh baja tulangan lentur untuk benda uji pile cap metode STM dan konvensioanal dapat dilihat pada Tabel 4.

Tabel 4. Kapasitas beban kondisi leleh baja tulangan lentur benda pile cap metode STM dan metode konvensional

\begin{tabular}{cccc}
\hline Metode & Benda Uji & $\begin{array}{c}\boldsymbol{P}_{\boldsymbol{y}} \\
(\mathbf{k N})\end{array}$ & $\begin{array}{c}\boldsymbol{P}_{\boldsymbol{y}} \text { rata-rata } \\
(\mathbf{k N})\end{array}$ \\
\hline \multirow{2}{*}{ STM } & PC-SS-4P-1 & 656,8 & 528,97 \\
& PC-SS-4P-2 & 354,4 & \\
\hline \multirow{2}{*}{ Konvensional } & PC-SS-4P-3 & 575,7 & 437,03 \\
& PC-KS-4P-1 & 427,3 & \\
\hline
\end{tabular}

Berdasarkan data di atas dapat dilihat bahwa dengan beban desain yang sama tetapi metode strut and tie model memiliki kapasitas beban yang lebih besar jika dibandingkan dengan dengan metode konvensional. Hal tersebut dibuktikan dengan peningkatan kapasitas beban kondisi leleh terhadap beban rencana pada benda uji pile cap metode STM adalah sebesar $32,2 \%$, sedangkan pada metode konvensional adalah sebesar 9,3\%. Untuk lebih jelasnya dapat dilihat pada Tabel 5 .

Tabel 5. Rasio beban kondisi leleh $\left(P_{y}\right)$ terhadap beban rencana $\left(P_{n}\right)$

\begin{tabular}{cccc}
\hline Metode & $\begin{array}{c}\boldsymbol{P}_{\boldsymbol{n}} \\
(\mathbf{k N})\end{array}$ & $\begin{array}{c}\boldsymbol{P}_{\boldsymbol{y}} \\
(\mathbf{k N})\end{array}$ & $\begin{array}{c}\text { Rasio } \boldsymbol{P}_{\boldsymbol{y}} \\
\text { terhadap } \boldsymbol{P}_{\boldsymbol{n}}\end{array}$ \\
\hline STM & 400 & 528,97 & 1,322 \\
Konvensional & 400 & 437,03 & 1,093 \\
\hline
\end{tabular}

\section{SIMPULAN}

Berdasarkan data hasil pengujian benda uji pile cap yang telah dilakukan, maka dapat ditarik beberapa kesimpulan antara lain: (1) Tulangan lentur yang mengalami kondisi leleh terlebih dahulu baik pada pengujian benda uji pile cap metode STM maupun pada metode konvensional adalah tulangan lentur arah X (tulangan lentur terluar). (2) Rata-rata regangan kondisi leleh dan beban pada benda uji pile cap metode STM adalah $2242 \mu \varepsilon$ dan 528,97 kN, sedangkan pada

\section{DAFTAR RUJUKAN}

Adebar, P., Kuchma, D., and Collins, M.P., 1990. Strut-and-Tie Models for the Design of Pile Caps: An Experimental Study. ACI Structural Journal. Vol. 87, No. 1, JanuayFebruary, pp. 81-91.

Badan Standar Nasional Indonesia, 2013. SNI 2847:2013 tentang Beton. Jakarta: Badan Standar Nasional Indonesia.

Blevot, J., L., and Fremy, R., 1967. Semelles sur Pieux. Institute metode konvensional adalah $2436 \mu \varepsilon$ dan $437,03 \mathrm{kN}$. (3) Peningkatan kapasitas beban kondisi leleh $\left(P_{y}\right)$ pada benda uji pile cap metode STM dan metode konvensional terhadap beban rencana $\left(P_{n}\right)$ adalah $32,2 \%$ dan $9,3 \%$. Hal tersebut mengindikasikan bahwa pile cap yang dirancang menggunakan metode strut and tie model (STM) lebih kuat jika dibandingkan dengan metode konvensional.

Technique du Batiment et des Travaux Publics. Vol. 20, No. 230, pp. 223-295.

Clarke, J., L., 1973. Behavior and Design of Pile Caps with Four Piles. Technical Report No. 42.489, Cement and Concrete Association, Wexham Springs.

Hardjasapurta dan Tumilar, 2002. Model Penunjang dan Pengikat (Strut-andTie Model) Pada Perancangan 
Struktur Beton. Jakarta: CV. Hidup Baru.

Hardjasapurta, H., 2016. Perancangan Beton Struktural Berdasarkan Model Strat dan Pengikat (Strut-and-Tie Model) SNI 2847:2013. Jakarta: Ref Graphika.

Martin, B., T., and Sanders, D., H., 2007. Verification and Implementation of Strut-and-Tie Model in LRFD Bridge Design Specification. NCHRP Project 20-07, Task 12, November 2007, pp. 276.

Morsch, E., 1902. Concrete-Steel Construction. New York: E. P. Goodrich, translation McGraw-Hill.

Pratama, G. N. I. P., \& Sumarjo, H. (2018). Aksesibilitas Tata Letak Elevator Penumpang Gedung Kantor Pusat Layanan Terpadu (KPLT) Fakultas Teknik UNY. INformasi dan Ekspose hasil Riset Teknik Slpil dan Arsitektur, 14(1), 26-35.

Ritter, W., 1899. "Die Bauweise Hennebique, Schweizerische Bauzeitung". Vol. 33, No. 7, February 1899, pp. 59-61.

Schlaich, J., Schäfer, K., and Jenewin, M., 1991. Design and Detailing of Structural Concrete. Journal of the Pre-stressed Concrete Insitute. Vol. 69, No. 6, Maret 1991, pp. 113-125.

Schlaich, J., Schäfer, K., and Jenewin, M., 1984, 1989, 1993. Konstruieren in Stahlbeton. Beton Kalender. BerlinMunich: Wilhem Ernst \& Son.

Schlaich, J., Schäfer, K., and Jenewin, M., 1987. Toward a Consistent Desaign of Structural Concrete. Journal of the Pre-stressed Concrete Insitute. Vol. 32, No. 3, pp. 74-150.

Shah, A., Haq, E., and Khan, S., 2011. Analysis dan Design of Disturbed Region in Concrete Structures. Procedia Engineering. Vol. 14, pp. 3317-3324.

Souza, R., Kuchma, D., Park, J.W., and Bittencourt. T., 2009. Adaptable Strut-and-Tie Model for Design and Verification of Four-Pile Caps. ACI Structural Journal. Vol. 106, No. 2, March-April, pp. 142-150.
Suhendro, B. 2000. Teori Model Struktur dan Teknik Eksperimental. Yogyakarta: Beta Offset.

Suzuki, K., and Otsuki, K., and Tsubata, T., 1999. Experimental Study on FourPile Caps with Taper. Transactions of the Japan Concrete Institute, Vol. 21, pp. 327-334.

Suzuki, K., and Otsuki, K., and Tsubata, T., 1998. Influence of Bar Arrangement on Ultimate Strength of Four-Pile Caps. Transactions of the Japan Concrete Institute, Vol. 20, pp. 195202.

Suzuki, K., and Otsuki, K., and Tsuhiya, T., 2000. Influence of Edge Distance on Failure Mechanism of Pile Caps. Transactions of the Japan Concrete Institute, Vol. 21, pp. 327-334.

Tjen N, Tjhin, and Daniel A, Kuchma, 2002. Computer-Based Beams Tools for Design by Strut-and-Tie Method: Advances Challenges. ACl Structural Journal, Vol. 99, No. 5, September-October 2002, pp. 586594. 